\title{
The invention of the basset hound: breed, blood and the late Victorian dog fancy, 1865-1900
}

DOI:

10.1080/13507486.2015.1070124

Link to publication record in Manchester Research Explorer

\section{Citation for published version (APA):}

Worboys, M., \& Pemberton, N. (2015). The invention of the basset hound: breed, blood and the late Victorian dog fancy, 1865-1900. European Review of History/Revue Europeene d'Histoire, 22, 726-40.

https://doi.org/10.1080/13507486.2015.1070124

\section{Published in:}

European Review of History/Revue Europeene d'Histoire

\section{Citing this paper}

Please note that where the full-text provided on Manchester Research Explorer is the Author Accepted Manuscript or Proof version this may differ from the final Published version. If citing, it is advised that you check and use the publisher's definitive version.

\section{General rights}

Copyright and moral rights for the publications made accessible in the Research Explorer are retained by the authors and/or other copyright owners and it is a condition of accessing publications that users recognise and abide by the legal requirements associated with these rights.

\section{Takedown policy}

If you believe that this document breaches copyright please refer to the University of Manchester's Takedown Procedures [http://man.ac.uk/04Y6Bo] or contact uml.scholarlycommunications@manchester.ac.uk providing relevant details, so we can investigate your claim.

\section{OPEN ACCESS}




\section{European Review of History: Revue européenne d'histoire}

\section{The invention of the basset hound: breed, blood and the late Victorian dog fancy, 1865-1900}

\section{Neil Pemberton \& Michael Worboys}

To cite this article: Neil Pemberton \& Michael Worboys (2015) The invention of the basset hound: breed, blood and the late Victorian dog fancy, 1865-1900, European Review of History: Revue européenne d'histoire, 22:5, 726-740, DOI: 10.1080/13507486.2015.1070124

To link to this article: https://doi.org/10.1080/13507486.2015.1070124

\section{曲 Published online: 24 Sep 2015.}

Submit your article to this journal

Џll Article views: 215

Q View related articles $₫$

View Crossmark data $\nearrow$

4 Citing articles: 2 View citing articles 


\title{
The invention of the basset hound: breed, blood and the late Victorian dog fancy, 1865-1900
}

\author{
Neil Pemberton* and Michael Worboys \\ CHSTM, University of Manchester, Manchester, United Kingdom
}

(Received 10 November 2014; accepted 13 June 2015)

\begin{abstract}
In this article the authors explore the practices and conceptualisations of British dog breeding and the showing of pedigree dogs by the 'the dog fancy', focusing specifically on the story of a single breed: the basset hound. This was not simply a story of British dog fanciers appropriating a French dog breed; indeed, this was impossible because the very notion of a dog 'breed', defined by conformation and legitimated by pedigree, was in the process of invention. They show how the British dog-show fancy chose one, from many and varied types of French hound, to be the basset hound, and how this choice was legitimated by reference to an imagined history, where the British dog fancy rescued a noble animal from French indifference to breed and blood. The chosen physical form was standardised to arbitrary ideal, but was by means no static. In the spirit of the times, it was 'improved', first by the empirical methods of animal breeders, using pedigrees to secure good and pure 'blood', and then by the application of science, particularly artificial insemination and hereditarian theories.
\end{abstract}

Keywords: basset hound; animal history; Victorian science; heredity; Britain; France; breeding; pedigree dogs

\section{Introduction}

In this article we explore the practices and conceptualisations of British dog breeding and the showing of pedigree dogs by the 'the dog fancy', focusing specifically on the story of a single breed - the basset hound. This was not simply a story of British dog fanciers appropriating a French dog breed; indeed, this was impossible because the very notion of a dog 'breed', defined by conformation and legitimated by pedigree, was in the process of invention. Across the Channel there was a spectrum of types, bred to suit hunting on different terrains, with fast, straight-legged, smooth-haired hounds for the open farmlands of northern France, to sturdier, crooked-legged, rough-haired dogs for the scrublands of the west coast. English basset-hound fanciers in the 1870s were aware of the varieties of forms across France, but chose one type, which was assumed to be the 'noblest' because it came from aristocratic kennels. ${ }^{1}$ What happened to the basset hound was typical of the way in which the Victorian dog fancy in Britain transformed the form, behaviour and identity of all varieties and types of dog, indigenous and foreign. As well as creating specific, conformation-defined breeds, they also established the very notion of a dog breed that spread across the world and is still with us today.

Our study of the basset hound in England is in four parts. After considering the historiography of dog breeds, we discuss briefly the development of the British dog-show fancy and its notion of breed. We next consider the place of the basset hound in France before the 1870s and how the varieties of short-legged hounds were understood and

*Corresponding author. Email: neil.pemberton@manchester.ac.uk 
classified. Next, we discuss the invention of the basset hound as a single-type 'breed' by the British dog-show fancy. ${ }^{2}$ We demonstrate how this choice was legitimated by reference to an imagined history, where the British dog fancy rescued a noble animal from French indifference to breed and blood. Finally, we consider Everett Millais's attempts to improve the breed, where he claimed to have introduced new blood by crossing with a British bloodhound, and re-establishing the ideal basset-hound conformation in just three generations. Millais's breeding programme provides a lens on contemporary breeding practices and ideas about inheritance, specifically the problems and virtues of inbreeding. Throughout this article we use the term dogs for all canines, though we are aware that some fanciers regarded (and still regard) hounds as distinct from dogs. This was (and is) partly a class phenomenon, distinguishing people with the wealth and land that have canines which hunt from those who do not.

\section{Breed histories}

Our approach to the invention of the modern basset hound is against the grain of much of the discussion that has dominated historical accounts of pedigree dog breeding and showing. The first wave of historical studies of the dog fancy largely contextualised the story in terms of British social and cultural history, in an attempt to explain why show dogs became a desirable pastime in mid-to-late nineteenth-century Britain. The social origin of the breeding and showing of pedigree dogs was the focus of Harriet Ritvo's pioneering The Animal Estate. ${ }^{3}$ Ritvo argued that British dog breeders' construction of breed standards, and manipulation of animal nature to manufacture dogs to specific conformations, provides a window upon British social relations, especially of class. For example, she contended that the idea of pedigree mirrored the aspirations of the upwardly mobile middle classes, who saw the social order as fluid and stable, enabling people and families with merit to 'improve' and for their success to be fixed.

More recent contributions that build upon Ritvo's foundational analysis emphasise the political contexts of the history of the dog and dog fancy, turning to questions of nationalism and national identity. In her analysis of how the British Pekingese Dog functioned as a potent object in the formation of British upper-class and imperialist femininities at the turn of the twentieth century, Sarah Cheang argues that pedigree dogs have served as powerful instruments in the articulation of nation, gender and class. ${ }^{4}$ And it is not just a British story. The enrolment of pedigree dogs in colonial and imperial projects was demonstrated in the recent work of Aaron Herald Skabelund on the role of canines in the making of modern Japan and van Sittert and Swart's work on dogs in South Africa. ${ }^{5}$ Such studies break new ground and exemplify the potential of the new cultural history, but have limitations, especially as their focus on representations has meant that the materiality of the dog, that is its physical form and behavioural characteristics, are not emphasised. Narratives of human projects are central; dogs can sometimes appear only as objects or metaphors. One exception is Ritvo's discussion of the conformation changes in the British bulldog, where once it entered the show ring, the breed was redefined and remade to have a different character and physique. ${ }^{6}$ Here we want to tell a history of a pedigree dog that grounds and relates representations of dogs in the material practices and results of dog-fancy aficionados.

\section{The dog-show fancy and breed}

The first modern dog show is typically traced to a competition held in June 1859 in Newcastle-upon-Tyne. ${ }^{7}$ The idea for such a venture came from Richard Brailsford, 
the head gamekeeper on the Knowsley estate of the Prime Minister Lord Derby. He proposed a show for sporting dogs on the 'same principles as Cattle, Sheep, Horse and Poultry Shows' and also for a society to improve the quality of the nation's dogs. His particular concern was the degeneration of pointers and setters, which were used as gun dogs in game shooting. He argued that the quality of fox hounds was kept high by selection in the best packs and that greyhounds were improved by breeding from the best racers, but that there was no effective quality control with pointers and setters, which were being inbred, promiscuously cross-bred, or both. Judging was on the 'look' or conformation of the dog, with the shape of the nose and body taken as indicators of good scenting and movement.

The following November Brailsford co-organised a dog show in Birmingham, styled the National Dog Show. It was held in association with the city's annual agricultural, poultry and horticultural shows. ${ }^{8}$ This was a larger event, with over 100 dogs, but there were misgivings about judging on conformation, as a report in a newspaper noted.

Of course the prizes could only be awarded for appearances, as no trial of their valuable points as sporting dogs took place. In a sporting point of view, therefore, the exhibition must be completely useless, as any sportsman knows that a handsome dog, as far as figure and flesh go, may be the veriest cur in the field, while many an ugly looking brute may be 'worth his weight in gold'?

The second Birmingham show followed in November 1860, organised by the self-styled National Dog Show Society. There were 206 sporting dogs entered, mostly pointers, setters, spaniels and bloodhounds, as well as 64 toy dogs and 'other general varieties not used in sport'. There was something for everyone: 'the luxurious "King Charles for fine ladies to fondle, and the three-seasoned "hunter" for the sportsman to dwell over'. ${ }^{10}$

The conformation dog shows came to London in 1861, but took off in 1862, when a show at Holborn did not include sporting dogs and was billed as an 'Exhibition of Fancy and other Dogs'. ${ }^{11}$ In the same year a 'Monster Dog Show' was organised at the New Agricultural Hall in Islington. There were over 1000 entries, including a pack of foxhounds from the Duke of Beaufort's estate at Badminton, and the famous painter Sir Edwin Landseer served as a judge. The promoters aimed to attract all social classes, charging $5 \mathrm{~s}$ for the exclusive opening day, halving that to attract the middle classes on the second day, before three public days at just $1 \mathrm{~s}$. The show attracted over 60,000 visitors, with London Review reporting that 'the plastic powers of art applied to nature' had never been shown more strikingly. Shows proliferated across the country and first enjoyed royal patronage in 1863, when the Prince of Wales and Princess Alice visited the Cremorne Show, along with the Duke and Duchess of Wellington and other members of the nobility.

Dog shows had rapidly become sites of middle- and upper-class sociability and fashion, but their standing was threatened by reports of sharp practice, if not outright fraud. Dogs were 'faked' by fanciers colouring the animals' coat or eyes, cropping ears or substituting the canine on display, while halls were noisy, smelly and known to spread diseases such as dog distemper. Furthermore, judges were accused of ignorance, bias and even accepting bribes. A report in The Field sympathised with the task of judging, particularly as there were no agreed standards for the different types of dog. ${ }^{12}$ Prizes, prestige and money were at stake and, as with other competitive sports at the time, there were calls for rules and regulations. One answer was for each show to have a standards committee for 'those gentlemen who possess a knowledge of any particular class of dog' to contribute their standard of perfection, and for the Committee to consider all the contributions and produce an agreed standard around parts and points. ${ }^{13}$ However, that did not resolve the issue of differences between shows; hence, there were calls for national 
rules and standards. Various attempts were made to introduce and enforce such a scheme, but none was successful until the creation of the Kennel Club in $1873 .{ }^{14}$

The Club published rules for shows, including the appointment of judges and, adapting the notion of 'points' from livestock shows, proposed specific shapes, sizes and colours for various parts of the dog's anatomy. It also published a stud book, a public record of the lineage of dogs to counter false claims about the identity of animals and preserve value. These essentially pragmatic measures, required for fair sport at shows, had profound consequences for dogs. The conformation standards defined a particular segmentation of dog varieties, which were termed breeds and created the way in which dogs have been classified since, even to the extent that the term 'mongrel' came to mean mixed or nonbreed. As a consequence, show dogs were remade and standardised within restricted physical forms, and this activity created a new language and new ideas for thinking about dogs and in turn new practices for breeding, feeding, training and treating dogs.

\section{French basset hounds}

The basset hound was first introduced to the English dog-show fancy in 1872, in the penultimate part of a series of 10 essays by Count de Couteulx de Canteleu on 'The History of the French Breed of Hounds in the Nineteenth Century' published in the sporting newspaper The Field. ${ }^{15}$ The dogs pictured bear little resemblance to the conformation set out when the breed was recognised by the Kennel Club in 1880. Indeed, they resemble a modern terrier and a dachshund, and emphasise the point that in France basset hounds were a varied type, defined by their function rather than form (Figure 1).

'Wildfowler' noted in 1879 that variety was also a feature of beagles in France.

There are eight?-nine Governmental departments in France, in each department beagles are employed, more or less, yet it is rare that, even in the same department, the beagles of one village are like those bred in the next, and to crown it all, every department goes in for a special general type. ${ }^{16}$

The British invention of breed with a single standard, conformation type was quite different to the French notion 'des races de chien'.

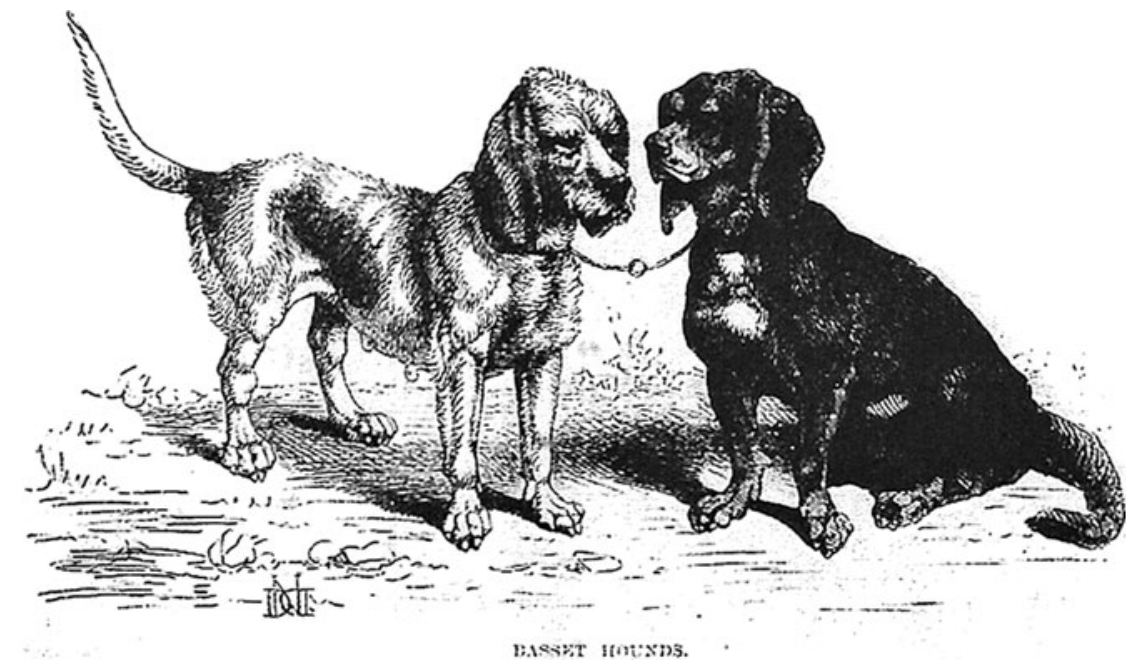

Figure 1. The Field, 1872, 40, 83. 
The common view amongst the British landed classes was that French hunting dogs had suffered a similar fate to the aristocracy after the Revolution, being killed or dispersed. According to 'The Wildfowler', 'a few hounds only escaped this "doggy" St Bartholomew, and eventually, when order was restored, the types had to be interbred, and also crossed with English blood, in order to replenish the various kennels then almost, if not quite, empty'. ${ }^{17}$ In this article in The Field, Count de Couteulx de Canteleu speculated that the basset hound might have its origins in a cross between a 'Skye or Scotch terrier with the Artesian or old Belgian hound', but British fanciers speculated on a noble heritage. ${ }^{18}$ George Krehl, editor of the Stock Keeper and Fancier's Chronicle and a basset breeder, told a story of a hound that had been preserved, through the 'many political storms that have swept over France', by the sporting and patriotic instincts of descendants of the old noblesse, Count de Couteulx de Canteleu. ${ }^{19}$ Some writers saw the type as a variant of the beagle and looked to similarities with the Spartan Hound of the Greeks and Romans, which was 'short-legged and deep mouthed'. Other speculated that Shakespeare perhaps had the basset hound in mind when he wrote these lines for Theseus in $A$ Midsummer Night's Dream:

My hounds are bred out of the Spartan kind,

So flew'd, so sanded, and their heads are hung

With ears that sweep away the morning dew;

Crook-knee'd, and dew-lapp'd like Thessalian bulls;

Slow in pursuit, but match'd in mouth like bells, ${ }^{20}$

The basset hound was also allegedly mentioned in The Noble Art of Venerie or Hunting, published in 1575, as the St Hubert Hound, a dog that was 'mighty of body, neuerthesse, their legges are lowe and short, likewise they are not swift, although very good of scent'. ${ }^{21}$ These hounds were said to have been bred by the monks of the Abbey of St Hubert in the Ardennes and used by the French aristocracy in hunting. Their sensitive noses, short legs and loud cries made them ideal for driving game in areas of dense vegetation. Krehl concurred with the view that the decline of the French aristocracy had led to the extinction of many types of hunting, but the basset survived. ${ }^{22}$

Against this speculation, 'Snapshot', the nom de plume of Lewis Clement, another authority on country sports, accepted its multiple forms. He noted that '[a]ny hound which stands lower than 16 in (no matter his "provincial" breed) is called in France and in Belgium a basset. ${ }^{23} \mathrm{He}$ tried to make sense of the variety in a classification based on the conformation of legs and coat. There were three types of leg: (1) à jambes droites, straight legged; (2) à jambes demi-torses, with forelegs half crooked; and (3) à jambes torses, forelegs fully crooked. There were also three varieties of coat, viz., the bassets à poil ras, smooth-coated; those à poil dur, rough-coated; and a class half rough half smooth-coated, which is called half griffons. ${ }^{24}$ This classification gave nine possible types of basset, which showed acclimatisation to different sports and terrains. For example, straight-legged, smooth-coated dogs were faster and suited to open country, while crooked-legged, roughcoated dogs were slower, better at digging and going to ground, and suited to scrub and forests. Varieties were further differentiated by coats being light or dark, and by the mix in tricolour (white, yellow, brown) dogs. National geographies intruded too, with speculation on the relationship of bassets in north-eastern France and Belgium to the dachshund, with one suggestion that the German dog should be called the 'Basset Allemand'. ${ }^{25}$

Britain's leading authority on dogs, John Henry Walsh, who wrote under the nom de plume 'Stonehenge', edited The Field and published many books of the dog and well as on sports. In the mid-1860s, Walsh had initiated a series of articles in The Field to define conformation standards for different types of dogs, principally to establish consistency in 
the judging of classes in the burgeoning number of dog shows taking place across Britain. The shows were a sensation in the 1860 s, first as adjuncts to agricultural shows and then as independent ventures. The shows offered prizes and prestige to dog breeders and owners, as well as entertainment for the public. Show organisers adopted the practices and language of agricultural shows, with competitions for the best animals in particular 'breed' classes, judged against standard points. The articles setting out suggested breed points were published by Walsh in 1867, under the title of Dogs of the British Islands, which became an influential reference book of standards. There were several editions, with new breeds added each time, with the basset hound being included for the first time in $1882 .{ }^{26}$ George Krehl wrote the new chapter on the basset hound. He dismissed the rough-coated hounds from the Vendée as inferior, in favour of 'the smoother and nobler race' that came from the northeastern regions of Artois and had been kept pure by the Couteulx family. Again, he emphasised History, suggesting that the smooth coated basset hound was 'quaint and picturesque, and in harmony with medieval character. They are the dogs one expects to see in tapestries and roaming round castle keeps. ${ }^{27}$

\section{A British breed}

Everett Millais, the eldest son of the leading Pre-Raphaelite painter John Everett Millais and Effie Gray, was the first person to show a basset hound at a British dog show at Wolverhampton in $1875 .{ }^{28}$ He had obtained his first basset hound whilst visiting Normandy in November 1873 and bought the dog he showed at Wolverhampton at a dog show in the Jardin d'Acclimatation in Paris the following year. ${ }^{29}$ French dog shows had caused no little amusement in Britain as the first in 1863, organised by the Société Imperiale d'Acclimatation in the Bois de Boulogne, did not judge by breed, but in classes such as 'Watch dogs', 'Little Pet Poodles' and 'Various Pet Dogs and Drawing Room Dogs'. There was a whole section of 'Exotic Dogs', including 'Dogs used for human food', 'Dogs untamed by man' or 'Dogs which have become wild' ${ }^{30}$ It is ironic, therefore, that Millais's show dog 'Model' was first shown in a 'Variety Class' and 'caused no little excitement and amusement' because of its novelty (Figure 2). ${ }^{31}$ Dog fanciers regarded the basset hound as a curiosity, because it had the body and head of a foxhound, but with the long ears of a bloodhound, all set on short, crooked legs. Some were quite disparaging, claiming that it was a mongrel. As Krehl remembered: 'Many pronounced it a turnspit, others an abnormal dachshund, while a few "remembered to have seen such dogs in old French hunting pictures.", 32

Millais bought other basset hounds and attempted to establish a kennel. His dogs were soon rivalled by those of the fourth Earl of Onslow, a young man who had recently inherited the family fortune and estate in Shropshire, and who would later become a Conservative grandee. Onslow may have kept basset hounds before Millais, but had them for hunting not for show. Millais's success and Onslow's interest led others, notably 'Wildfowler' and Krehl, to import and breed from the best hounds from France. Onslow joined the show world too, as at the 1880 Kennel Club Show, Millais and Onslow provided all of the entries in the basset-hound class. ${ }^{33}$ Along with 'Model', Millais showed 'Garenne', and Onslow showed 'Nestor' and 'Fino'. All were of the 'Couteulx' type by then - the basset hound, a fact recognised in the same year when it was recognised by the Kennel Club. However, both men soon abandoned the breed. Lord Onslow's political career took up more time and Millais left the country for Australia. Publicly, this was to improve his physical health, though privately it was because his parents were concerned about his mental health. ${ }^{34}$ Their eldest son's drinking and consequent behaviour was leading to suggestions that there was degeneracy in the family. ${ }^{35}$ 


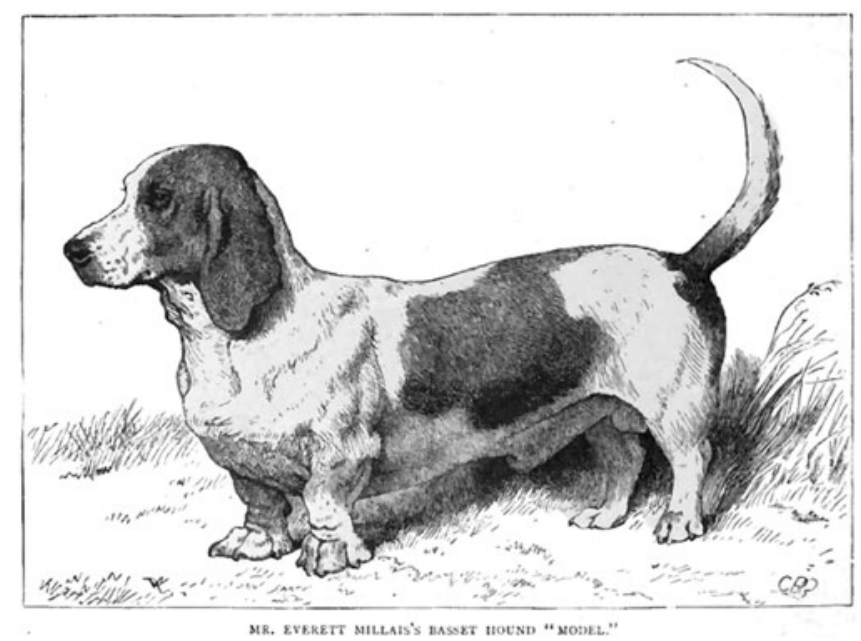

Figure 2. Vero Shaw, The Illustrated Book of the Dog (London: Cassell, Fetter, Galpin and Co., 1881). 'The illustration, by Mr C. B. Barber, ... is in our opinion, an exact representation of that well-known dog, whose name will never cease to be associated with the introduction of the breed into this country' (338).

The baton of championing the basset hound passed to Krehl, who had previously bred Irish terriers and bull dogs. He bought three Couteulx types at the Jardin d'Acclimatation show in 1880: 'Pallas', 'Jupiter' and 'Fino de Paris', the latter becoming a much sought after stud dog (Figure 3). Basset-hound classes became a regular feature in National Dog Shows in Birmingham and the Kennel Club Shows at the Crystal Palace. ${ }^{36}$ In a show in 1886 at the Royal Aquarium, over 50 basset hounds were entered, demonstrating that the breed had become popular with the dog fancy. ${ }^{37}$ Indeed, some reports wondered if it would soon overtake its German cousin the Dachshund in popularity and there were attempts to introduced non-Couteulx varieties. For example, a French dog breeder, Monsieur Louis

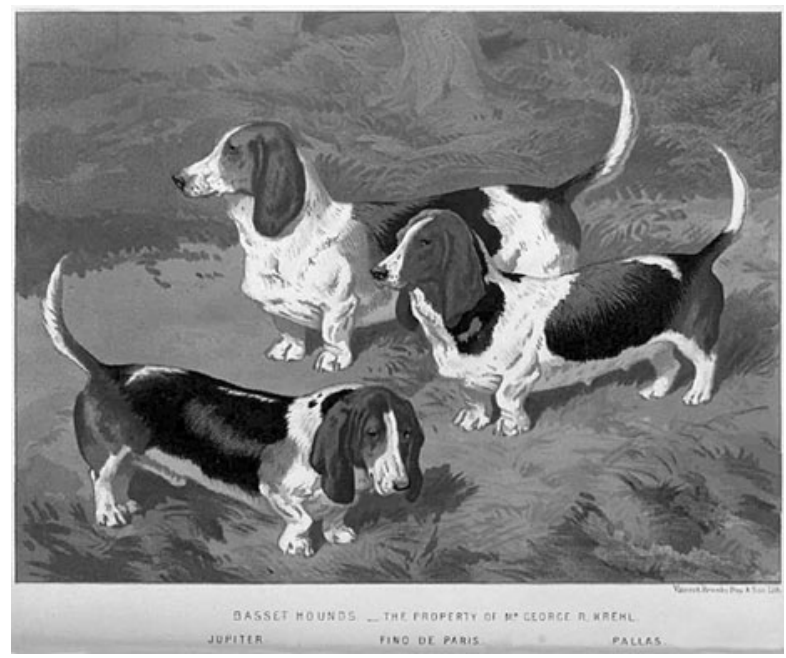

Figure 3. Vero Shaw, The Illustrated Book of the Dog (London: Cassell, Fetter, Galpin and Co., 1881), p. 337. 
Lane from Francqueville, brought over a larger, smooth-coated, lemon-coloured, which he hoped would be acceptable to both the sportsman and the exhibitor. ${ }^{38}$ However, the most fashionable new addition was the rough-coated Griffon basset. Its leading breeder was Mrs Mabel Tottie, who had large kennels at Coniston Hall, near Skipton in Yorkshire, and also kept smooth-coated hounds. ${ }^{39}$ Princess Alexandra also kept both types, with 'a whole troop' at Royal Kennels at Sandringham, thus giving royal approval to the breed. ${ }^{40}$ Roughcoated hounds became more popular in the 1890s. At Cruft's Dog Show in 1894, the Prince of Wales entered three rough-coated dogs and one bitch, winning a second and third prize.

The breeding and keeping of basset hounds was also taken up by the British hunting fraternity and in this sphere there was dispute about the 'correct' conformation. The dogs had been used in France for hare and rabbit hunting, which seemed odd to English fanciers as their short legs and heavy bone limited their speed. However, one owner of a hunting pack, Frederick Blain, wrote in the 1899 edition of British Dogs that: 'They are by no means as slow as people imagine, and they will go on for hours at top speed, showing endurance and pluck. ${ }^{41} \mathrm{He}$ hoped that owners of hunting packs, "will not neglect the heavy, somewhat ungainly appearance that they should have, and gradually get them higher on the leg and lighter on the bone and body; by so doing they may increase speed, but they will lose endurance, and they will in time be nothing better than deformed Beagles. ${ }^{42}$ Basset hounds were used for scenting as well as hunting, being particularly prized for their sensitive nose, and ability to follow a scent for hours. They were used to track foxes and deer, where their loud cry was valued in flushing game out of its cover. Bassets were also seemingly fun to hunt with because of their 'enthusiasm', their 'music' and the 'enchantment' of working with such an amusingly conformed dog. ${ }^{43}$

\section{British blood}

During his exile, Everett Millais had spent time exploring and hunting, and developed an interest in natural history and science. When he returned to Britain, he took up dog breeding again and became an expert in artificial insemination; indeed, in some histories of the subject his name appears alongside that of eighteenth-century pioneers of the biology of reproduction Lazzaro Spallanzani. ${ }^{44} \mathrm{He}$ also worked in bacteriology, publishing an article in the British Medical Journal in April 1890 in which he reported isolating the bacillus of dog distemper and developing a vaccine. ${ }^{45}$ Neither claim stood the test of time, but his growing standing in metropolitan scientific circles was indicated by his election to the Physiological Society. ${ }^{46}$

On his return from Australia, Millais quickly re-joined the dog fancy. He was surprised, first, at the attention which basset hounds attracted at the Kennel Club Show in 1884 , and second that 'Model' was still fertile and at stud. ${ }^{47}$ Back in the late 1870 s, when he believed 'Model' to be the only basset hound in Britain, Millais had crossed him with an English beagle bitch, exhibiting the resulting dog as a basset hound in 1877 at a show in the Agricultural Hall, London. ${ }^{48}$ Subsequently, he bred his basset-beagle crosses only with pure bassets, increasing the 'basset factor until the beagle type was destroyed'. ${ }^{49}$ Millais had worked with the common 'fraction theory' or 'equal factor system' of breeding, where by after each mating time with a pure-bred basset hound, the beagle factor would be reduced first to a half, than a quarter, then an eighth and so on, down to just one thousandth in just ten generations.

In 1884, Millais was a founder member of the Basset Hound Club, along with Lord Onslow and George Krehl. Still enamoured with 'Model', Millais bought a bitch - 
'Finette II' - to breed from his old favourite. Amongst basset-hound fanciers, it was known that basset hounds were hard to breed with. They did not become pregnant easily and had small litters, with many pups stillborn. The underlying reason was assumed by fanciers to be inbreeding, a result of the limited number of basset hounds in the country, and practice of going to the small number of class-winning dogs to 'improve' a owner's stock. In fact, Millais's Finette II was Model's great-granddaughter, which he later described as 'in-and-in breeding with a vengeance' ${ }^{50}$ He wrote that he was prompted to pursue cross-breeding when Sir Clifford Allbutt, then in Leeds, but soon to be Regius Professor of Physics at Cambridge, returned a basset hound that Millais had given him stating that it was a canine 'idiot'. 51

The dominant medical understanding of madness in humans at this time was that heredity was a major factor in its incidence, shown by the fact that it ran in families. ${ }^{52}$ However, Millais criticised those who maintained that inbreeding was inevitably 'wrong, unnatural and absolute ruin to the stock on which it is practised', arguing instead that it was only damaging if carried too far. ${ }^{53} \mathrm{He}$ used Darwinian ideas on speciation to claim that inbreeding was common in Nature; indeed, it was inevitable in small, geographically isolated populations and essential to fix the features Nature selected. Millais only saw problems when no 'new blood' was brought in for many generations. A rule of thumb that breeders used was 'twice in and once out'. The problems most commonly reported in inbred dogs were said to be epilepsy and other mental conditions, which confirmed the wider medical view that mental degeneration set in more quickly than physical. ${ }^{54}$ Millais had kept detailed records both of his normal and 'experimental' breeding, and he had kept up with the latest biological work on heredity, physiology and bacteriology, and their inter-relations. For example, inbred dogs were said to be more susceptible to distemper and hence needed to be well fed and in good condition. He had undertaken his distemper work in the laboratories of C. S. Sherrington at St Thomas's Hospital, London and, as his association with Clifford Allbutt shows, moved in elite scientific circles. His work and thinking on heredity had been presented in a book called The Theory and Practice of Rational Breeding in 1889. ${ }^{55}$ He also kept a Basset Hound Stud Book, the pedigrees of which Francis Galton used in his work on ancestral heredity, focusing on the inheritance of tricolour. $^{56}$

The first breeding problem that Millais addressed was securing fertile mating, adopting artificial insemination, collecting dog semen and introducing it into bitches on heat via a syringe. He published his first results in the Veterinary Journal in $1884 .{ }^{57}$ Between 1884 and 1896 he made 17 further 'experiments', details of which were communicated to the Royal Society in February 1897 by the Cambridge embryologist Walter Heape, in a paper read by Francis Galton. ${ }^{58}$ His first attempts in 1884 succeeded with conception, but all the puppies were born dead. He tried again in 1885, inseminating three bitches from the same batch of semen and produced live young. As noted already, the breed was subject to barrenness and had a constitutional vulnerability to distemper, a disease that Millais campaigned to control at dog shows as well as research. ${ }^{59}$ Both characteristics were understood to be signs of degeneration from successive and excessive inbreeding.

In order to overcome degeneration due to inbreeding in British basset hounds, Millais adopted a radical solution - crossing his basset hounds with English bloodhounds. ${ }^{60}$ He wanted to introduce new blood and increase the size of his hounds. While aimed to counter the deleterious effects of inbreeding, the experiment was also said to show its value in that the purity and quality of the blood of his hounds enabled him to breed back to the basset conformation in just three generations. In 1891 Millais had successfully inseminated a bloodhound bitch with semen from a basset hound called 'Floreal', using 
artificial insemination, both to increase the chances of conception and to overcome height differences. The results were not reported. He tried again with his hound 'Nicholas', which he put to a bloodhound bitch called, not without irony, 'Inoculation'. He knew 'Nicholas's' pedigree back seven generations and stated that he ought to have 128 ancestors, but had just eight and contained 'almost half' of the blood of the much-prized 'Fino de Paris'. Inbreeding with the 'equal system' of inheritance concentrated 'blood'; hence, a pure-bred descendant of 'Fino de Paris' like 'Nicholas' was an 'unequal' contributor of 'blood'. Millais told an audience at St Thomas's Hospital in February 1895 that such a well-bred animal exemplified pedigree, not just the lineage, but 'the power of reproducing its own type in whatsoever female it is mated with' ${ }^{61}$ Millais wrote that:

I chose the Bloodhound, firstly, because the head of the Basset should resemble that of the Bloodhound; and secondly, because from my experimental work with Beagles, I knew that the question of a return to Basset formation in legs was but a matter of one or two generations. There therefore remained simply the question of colour, and this I was certain would come back very speedily. ${ }^{62}$

He also felt the hounds in France were not in the "same state of perfection as it has been brought to in England'. ${ }^{63}$ In 1890 he had quoted the French dog breeder Monsieur E. Frechon on the differences between the breeding cultures of the two countries:

Whereas we in France leave everything to luck, awaiting some fortuitous and unforeseen circumstance to produce superior types in a breed, over there (England) they have for ages modified the laws which regulate crossing. They have, I might almost say, 'weighed' the exact proportion of blood necessary to be added, through several generations, to that of some celebrated individual, to ensure in the end his type and attributes. ${ }^{64}$

Millais had great confidence in the power of 'Fino de Paris's' blood and, more generally, in malleability of the physical form of dogs, not least expecting to lose the long, straight legs of the bloodhound and re-establish short, crooked legs of the basset hound in very few generations.

The mating of 'Nicholas' with 'Inoculation' produced 12 puppies, which were delivered by Caesarean because the bitch was dying. ${ }^{65}$ Seven were reared and all resembled 'Nicholas'. Millais then proceeded, using artificial insemination to avoid any chance of contamination, to cross these half-bred bitches to a purebred basset hound. Next, one of the puppies of this cross, which he called three-quarter bred, was put to another purebred basset hound. In the lecture Millais projected photographs showing how, with each litter, the physical form of the puppies moved towards not just the basset-hound conformation standard. ${ }^{66}$ His conclusion, essentially replicating his experience with basset houndbeagle crosses in the 1870 s, was that breeders could re-establish a breed's physical conformation within relatively few generations. Thus, fanciers had no need to inbreed excessively; new blood could be introduced regularly, with the physical form taken back to the breed standard by breeding in just three generations. Millais boldly declared that 'the Basset of today in England is practically a new variety founded on the individual character of a Hound, named Fino de Paris, which used to stand at stud in ... Paris' ${ }^{67}$ To the suggestion of French breeders that 'we have changed the type', he answered: 'Gentlemen, we have not changed the French basset in any manner whatever; we have made a variety, founded on their best. ${ }^{68}$ In fact, Millais and other British breeders had taken a group of hounds of great variety and made one physical conformation a breed.

'Fino de Paris' continued to set the breed standard. After the 1890s, rough-coated basset hounds fell out of favour; in shows and in hunts they were said to be 'not so staunch or painstaking in their work', 'their colouring less distinct and their note less rich'. ${ }^{69}$ In France, the Société Centrale Canine continued to recognise several 'races' - their term for 

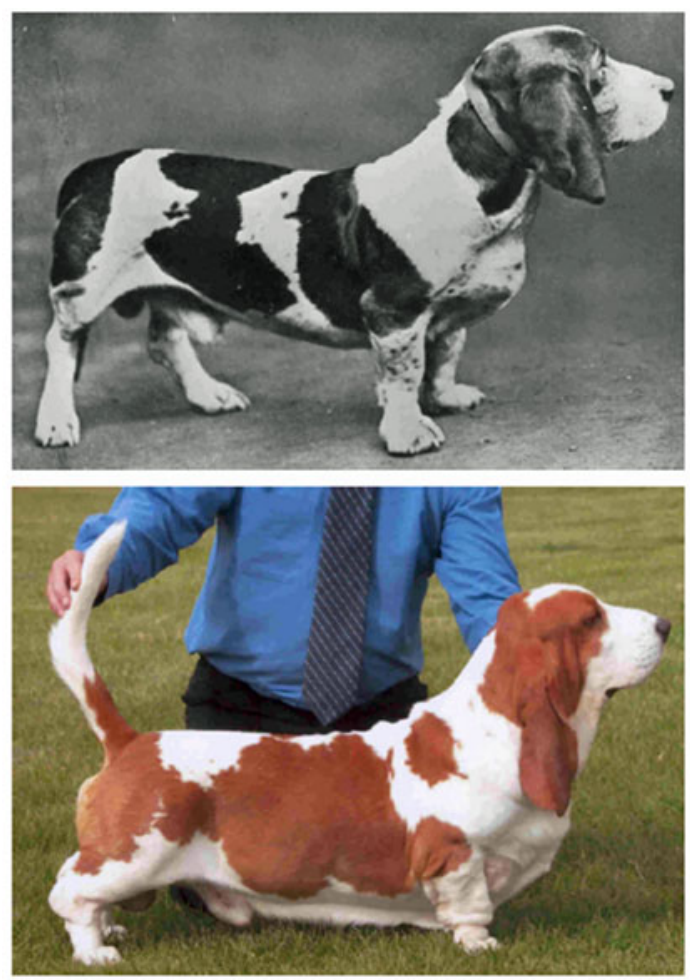

Basset Hound in 1901 (above) and in 2004 (below)

Figure 4. Patrick Bateson, Independent Report into Dog Breeding (London: Kennel Club, 2010), p. 32 .

'breed' - and today these still reflect the country's regions: Basset Artesien Normand; Basset Bleu de Gascogne; Basset de Westphalie; Basset des Alpes; Basset Fauve de Bretagne; Basset Suedois; Grand Basset Griffon Vendeen; and Petit Basset Griffon Vendeen. They also recognise the 'Basset Hound', that is, the British manufacture, which is now controversial because breeders changed its conformation so much over the twentieth century that it is now recognised to have several unhealthy features. Indeed, it was featured in the Bateson Report into pedigree breeding practices in 2009, as one where features had changed most over the twentieth century (Figure 4). Modern hounds are genetically more diverse, because coefficients of inbreeding are monitored, but breeders and owners have shown preferences for certain physical features, often justified by reference to breed histories.

\section{Conclusion}

Everett Millais remains well known amongst basset-hound breeders and owners today as the person who contributed most to the development of the modern basset hound. He introduced the breed to Britain, established its place in dog shows, defined the breed standard, improved the breed with his bloodhound outcross, and, more speculatively, through this cross made the breed larger and stronger. Indeed, one consequence of the 'Nicholas-Inoculation' cross, which still has currency amongst fanciers, is that it gave 
basset hounds the highest bone-to-weight ratio of any dog breed. How many of these 'contributions' can solely be attributed to Millais is debatable, but what is clear is that, along with other contemporary enthusiasts, he was passionately interested in the physical form of the basset hound. Dog breeders and fanciers wanted the dogs with the 'correct' conformation to win show prizes, to earn stud fees and to help build their reputation in the dog fancy. They were also concerned, to an extent, with welfare; healthier dogs looked better, lived longer and earned more. Thus, our history of the basset hound, which emphasises physicality, is one that would have been recognised by nineteenth-century breeders and owners, though sociality, reading and above all experience were deeply involved in the practices that physically reshaped dogs.

But what of the cultural history of the basset hound? What did it mean to Victorian 'doggy people' in Britain to have appropriated a French dog? Was there a frisson in owning and showing a Gallic import? Seemingly not. Fanciers celebrated that they had remade the breed; it was improved and standardised, and individual dogs proved their worth in competition. Harriet Ritvo suggested that the English dog fancy, through its interest in breed and pedigree was simulating aristocratic values. This was certainly the case with many breeds, but our story of the remaking of the basset hound has shown the importance of breed entrepreneurs and of science, qualities firmly associated with the British entrepreneurial and professional middle classes.

\section{Disclosure statement}

No potential conflict of interest was reported by the authors.

\section{Funding}

This work was supported by the Arts and Humanities Research Council [grant number AH/ H030808/1].

\section{Notes}

1. Stonehenge, Dogs of the British Islands, editions in 1867, 1872, 1878 and 1882. The basset hound was first included in the $4^{\text {th }}$ edition in 1882 .

2. Balogh, "The Early History of the Basset Hound in England."

3. For a more recent history of pedigree animal breeding see Derry, Bred for Perfection; Ritvo, The Animal Estate, 82-121.

4. Cheang, "Women, Pets and Imperialism," 359-87. For a cultural history of the interlinked mythologies and national myths surrounding the pedigree English bloodhounds see: Pemberton, "Bloodhounds as Detectives," 69-91.

5. Skabelund, Empire of Dogs; Sittert and Swart, "Canis Familiaris," 138-73; Swart, "Dogs and Dogma," 190-206.

6. Ritvo, The Animal Estate, 107-13.

7. Ibid.

8. Oliver, From Little Acorns, 7-8.

9. Anon., "Prize Dogs," 3b.

10. Anon., "The Dog Show at Birmingham," 8d.

11. Advertisement, "MONSTER SHOW," 1.

12. Anon., "The Birmingham Dog Show of 1863," 557.

13. "W W," Rules for Judging, 407.

14. Jaquet, The Kennel Club, 1-11.

15. Couteulx de Canteleu, "French Breed of Hounds," PP; Couteulx de Canteleu, Les races de chiens courans français au XIXe siècle.

16. "Wildfowler," Shooting Adventures, 273.

17. "Wildfowler," Shooting Adventures, 60. 
18. Couteulx de Canteleu, "French Breed of Hounds," 83.

19. Krehl, "The Basset Hound," 158.

20. Shakespeare, A Midsummer Night's Dream, Act IV, Scene 1.

21. Turbeville, The Noble Art of Venerie or Hunting.

22. Krehl, "The Basset Hound," 157-9.

23. "Wildfowler," Shooting Adventures, 267.

24. Snapshot, "The Basset Hound," 84.

25. Shaw, Illustrated Book of the Dog, 333.

26. Stonehenge, 1882.

27. Krehl, "The Basset Hound," 158.

28. Millais was not the first person to own basset hounds in Britain. The Earl of Onslow had been given a different type - Millais, "Bassets"; Worboys, "Millais, Sir Everett."

29. Letter.

30. Anon., "Paris Dog Show"; Anon., "Dog Show for the French Acclimatisation Society."

31. Walsh, Dogs of the British Islands, 157.

32. Krehl, "The Basset Hound," 157-61.

33. Anon., "The Dog Show."

34. Cooper, The Model Wife, 176-8.

35. Ibid., 177.

36. Times, 4 June 1880, 6b; 25 August 1881, 9e; 6 July 1883, 3e; 4 December 1883, 7f; 1 December $1884,7 \mathrm{c} ; 4$ February 1886, 12c; 2 July 1886, 3f.

37. Illustrated London News, 29 May 1886, 6.

38. Krehl, "The Basset Hound," 160.

39. Lane, Doggy Shows, 239-42.

40. Anon., "H. R. H. The Princess of Wales's Pet Dogs," Bolton, "H. R. H. The Princess of Wales"s Kennels;" Jessop, "The Princess of Wales's Dogs."

41. Drury, British Dogs, 208.

42. Ibid., 213.

43. Ibid., 214.

44. Heape, "Artificial Insemination of Mammals," 52-63; Millais, "Artificial Impregnation," $256-8$.

45. Millais, "The Pathogenic Microbe of Distemper," 856.

46. O'Connor, British Physiologists, 534.

47. Anon., Illustrated London News, 5 May 1884, 7c.

48. Millais, Theory and Practice of Rational Breeding, 55.

49. Ibid.

50. Quoted by Balogh, "The Early History of the Basset Hound in England."

51. Millais, Theory and Practice of Rational Breeding, 49.

52. Pick, Faces of Degeneration.

53. Millais, Theory and Practice of Rational Breeding, 41.

54. Maudsley, "An Address on Medical Psychology."

55. Millais, Theory and Practice of Rational Breeding.

56. Galton Archive.

57. Millais, "Artificial Impregnation," 256.

58. Heape, "The Artificial Insemination of Mammals," 52-63.

59. Millais, "Distemper," 45-74.

60. Millais, "Basset Bloodhounds."

61. Millais, Two Problems of Reproduction, 32.

62. Ibid.

63. Millais, Two Problems of Reproduction, 55.

64. Millais, Theory and Practice of Rational Breeding, vii.

65. Millais, "Two Problems of Reproduction," 10

66. Ibid., 33-7.

67. Ibid., 29.

68. Ibid.

69. Ellis, "The Basset-Hound," 303. 


\section{Notes on contributors}

Neil Pemberton is a Wellcome Research Associate in the Centre for the History of Medicine, Science and Technology at the University of Manchester. He has published a number of books and articles on a wide number of historical topics, including the rat-catching techniques and the history of the forensics of homicide.

Michael Worboys is a Emeritus Professor in the Centre for the History of Science, Technology and Medicine at the University of Manchester. He works on the history of infectious diseases and has recently published, with Neil Pemberton, Rabies in Britain: Dogs, Disease and Culture, 1830-2000 (Basingstoke: Palgrave 2012)

\section{Bibliography}

Advertisement. "MONSTER SHOW of Sporting and all other breed of DOGS." Bell's Life in London and Sporting Chronicle, 15 June 1862, 1.

Anon. "Prize Dogs." Berrow's Worcester Journal, 3 Dec. 1859, 3 b.

Anon. "The Dog Show at Birmingham." Bell's Life of London and Sporting Chronicle, 9 Dec. 1860, $8 d$.

Anon. "Birmingham Dog Show of 1863." The Field, 5 Dec. 1863, 557-558.

Anon. "Dog Show for the French Acclimatisation Society." The Field, 14 March 1863, 248.

Anon. "Paris Dog Show: Jardin d'Acclimatation (Bois de Boulogne)." The Field, 9 May 1863, 430 and (16 May 1863), 455.

Anon. "The Dog Show." Times, 5 June 1880, 6 b.

Anon. "H. R.H. The Princess of Wales's Pet Dogs." Country Life Illustrated, 8 Jan. 1897, 17-20.

Balogh, Eva S. "The Early History of the Basset Hound in England, 1874-1921.” http://www.basset. net/index.php?page=the-early-history-of-the-basset-hound-in-england-1874-1921. (Accessed 5 May 2012).

Bateson, P. Independent Report into Dog Breeding. London: Kennel Club, 2010.

Bolton, Gambier. "H. R.H. The Princess of Wales's Kennels." Country Life Illustrated, 16 January $1897,50-52$.

Cheang, S. "Women, Pets and Imperialism: the British Pekingese Dog and Nostalgia for Old China." Journal of British Studies 45 (2006): 359-387.

Cooper, Susan Fagance. The Model Wife: The Passionate Lives of Effie Gray, Ruskin and Millais. London: Gerald Duckworth and Co, 2010.

Couteulx de Canteleu, Le Count. "The History of the French Breed of Hounds in the Nineteenth Century." The Field, 27 July 1872, 39, 83.

Couteulx de Canteleu, Le Count. Les races de chiens courans français au XIXe siècle. Paris, 1873.

Dalziel, Hugh, ed. British Dogs: Their Varieties, History, Characteristics, Breeding, Management and Exhibition. London: The Bazaar Office, 1879.

Derry, Margaret D. Bred for Perfection: Shorthorn Cattle, Collies, and Arabian Horses Since 1800. Baltimore: Johns Hopkins University Press, 2003.

Drury, William D. British Dogs, their Points, Selection, and Show Preparation. 4th ed. London: L. Upcott Gill, 1903.

Ellis, C. C. "The Basset-Hound." In The New Book of the Dog, edited by Rawdon Lee. London: Cassell and Co, 1907.

Heape, Walter. "The Artificial Insemination of Mammals and Subsequent Fertilisation or Impregnation of heir Ova." Proceedings of the Royal Society of London, Biological Sciences 62 (1897): 52-63.

Jaquet, Edward T. The Kennel Club: A History and Record of its Work. London: The Kennel Club, 1905.

Jessop, Ernest M. “The Princess of Wales's Dogs.” The Girl's Own Paper, 16 June 1900, 577-581.

Krehl, George. "The Basset Hound." In Dogs of the British Islands: Being a Series of Articles and Letters by Various Contributors, Reprinted from the "Field" Newspaper, edited by J. H. Walsh. 4th edn 157-161. London: Horace Cox, 1882.

Lane, E. C. Dog Shows and Doggy-People. London: Hutchinson and Co, 1902.

Lee, Rawdon, ed. The New Book of the Dog. London: Cassell and Co, 1907.

Maudsley, Henry. "An Address on Medical Psychology." Lancet, ii, 1872, 185-189. 
Millais, Everett. "Bassets: Their Use and Breeding.".

Millais, Everett. "Distemper." Dog Owner's Annual, 45-74, Manchester, 1890.

Millais, Everett. "The Pathogenic Microbe of Distemper in Dogs, and its Use for Protective Inoculation." British Medical Journal i (1890): 856-859.

Millais, Everett. “Artificial Impregnation.” Veterinary Journal 18 (1884): 256-258, Published under the nom de plume "A Dog Breeder."

Millais, Everett. The Theory and Practice of Rational Breeding. London: Fanciers Gazette, 1889.

Millais, Everett. Two Problems of Reproduction, Lecture Delivered at St. Thomas Hospital 25 February 1895. London: Fanciers Gazette, 1895.

Millais, Everett. "Basset Bloodhounds: Their Origin, Raison d'Etre and Value." Dog Owner's Annual (1897): 25-30.

O’Connor, Walter John. British Physiologists A Biographical Dictionary. Manchester: Manchester University Press, 1991.

Oliver, A. From Little Acorns: The History of the Birmingham Dog Show Society Estd 1859. Birmingham: Birmingham Dog Show Society, 1998.

Pemberton, Neil. "'Bloodhounds as Detectives': Dogs, Slum Stench and Late-Victorian Murder Investigation." Cultural and Social History 10, no. 1 (2013): 69-91.

Pick, Daniel. Faces of Degeneration: A European Disorder, c. 1848-1918. Cambridge: Cambridge University Press, 1993.

Ritvo, Harriet. The Animal Estate: The English and Other Creatures in the Victorian Age. Cambridge, MA: Harvard University Press, 1987.

Shakespeare, William. A Midsummer Night's Dream, Act IV, Scene 1.

"Snapshot." "The Basset Hound." In British Dogs: Their Varieties, History, Characteristics, Breeding, Management and Exhibition, edited by Hugh Dalziel, 83-91. London: The Bazaar Office, 1879.

Shaw, Verso. The Illustrated Book of the Dog. London: Cassell, Fetter, Galpin and Co., 1881.

Skabelund, A. H. Empire of Dogs: Canines, Japan, and the Making of the Modern Imperial World. Ithaca: Cornell University Press, 2011.

Stonehenge (aka John Henry Walsh). The Dogs of the British Islands. London: Horace Cox, 1882.

Swart, Sandra. "Dogs and Dogma: A Discussion of the Socio-Political Construction of Southern African Dog 'Breeds' as a Window on Social History." South African Historical Journal 48, no. 1 (2003): 190-206.

Turbeville, George. The Noble Art of Venerie or Hunting etc. London: Thomas Purfoot, 1611.

Van Sittert, Lance, and Swart, Sandra. "Canis Familiaris: A Dog History of South Africa." South African Historical Journal 48, no. 1 (2003): 138-173.

Wildfowler. Shooting Adventures, Canine Lore and Fishing Trips, vol. 2. London: Chapman Hall, 1879.

Worboys, Michael. "Millais, Sir Everett, Second Baronet (1856-1897)." Oxford Dictionary of National Biography, Oxford University Press, Sep. 2014. http://www.oxforddnb.com/view/ article/105376 (Accessed 10 October 2014).

"W W." "Rules for Judging a Dog Shows." The Field, 11 June 1864, 407. 